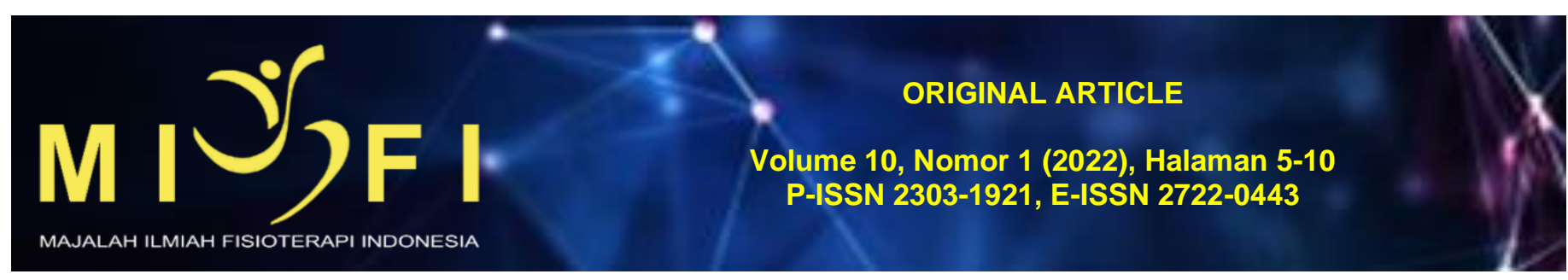

\title{
HUBUNGAN ANTARA AKTIVITAS FISIK TERHADAP KOORDINASI MATA TANGAN PADA LANSIA DI DESA GERIH
}

\author{
Ketut Resa Indar Parwangsa ${ }^{1^{*}}$, Putu Ayu Sita Saraswati ${ }^{2}$, I Putu Yudi Pramana Putra ${ }^{3}$, \\ I Wayan Gede Sutadarma ${ }^{4}$ \\ ${ }^{1}$ Program Studi Sarjana Fisioterapi dan Profesi Fisioterapi, Fakultas Kedokteran, Universitas Udayana, Denpasar, Bali \\ 2,3 Departemen Fisioterapi, Fakultas Kedokteran, Universitas Udayana, Denpasar, Bali \\ ${ }^{4}$ Departemen Biokimia, Fakultas Kedokteran Universitas Udayana, Denpasar, Bali \\ "Koresponden: indarp03@gmail.com
}

Diajukan: 16 Juni 2021 | Diterima: 20 Juni 2021 | Diterbitkan: 25 Januari 2022

DOI: https://doi.org/10.24843/MIFI.2022.v10.i01.p02

\begin{abstract}
ABSTRAK
Pendahuluan: Kemampuan fisik seseorang lambat laun akan menurun akibat dari proses penuaan. Koordinasi mata tangan merupakan salah satu kemampuan fisik yang menurun akibat penuaan. Suatu hubungan kompleks antara sistem visual dan motorik yang memiliki suatu tujuan seperti menunjuk, meraih, dan mencakup seluruh kegiatan sehari hari merupakan definisi dari koordinasi mata tangan. Salah satu cara untuk mencegah maupun meningkatkan fungsi koordinasi mata tangan yaitu dengan melakukan aktivitas fisik. Meningkatkan aktivitas fisik dipercaya sebagai tindakan pencegahan dan pengobatan terhadap penyakit dan kecacatan pada lanjut usia (Lansia). Tujuan dari penelitian ini adalah untuk mengevaluasi bagaimana hubungan aktivitas fisik terhadap koordinasi mata tangan pada lansia di Desa Gerih.

Metode: Penelitian ini merupakan penelitian cross-sectional (potong lintang) dengan menggunakan teknik sampling total sampling. Jumlah sampel yang diperoleh pada penelitian ini adalah 44 sampel yang sesuai dengan kriteria inklusi, eksklusi dan drop out yang telah ditentukan. Pengumpulan data dilakukan dengan mengukur aktivitas fisik baecke index dan koordinasi mata tangan menggunakan alternate hand wall toss test.

Hasil: Berdasarkan uji analisis non parametrik spearman rho didapatkan nilai $p=0,017(p<0,05)$ dan koefisien korelasi $r=0,359$.

Simpulan: Berdasarkan hasil yang didapatkan dari penelitian ini, bisa kita katakan bahwa terdapat hubungan antara aktivitas fisik terhadap koordinasi mata tangan pada lansia di Desa Gerih.
\end{abstract}

Kata Kunci: aktivitas fisik, koordinasi mata tangan, lansia

\section{PENDAHULUAN}

World Health Organization (WHO) menyatakan jumlah lansia yang menigkat secara signifikan di Indonesia menjadikan negara kita masuk ke dalam salah satu dari lima negara dengan populasi lansia yang tinggi di dunia. Jumlah penduduk lanjut usia di Bali pada tahun 2016 adalah 440.000 jiwa dari 4,2 juta jiwa total penduduk. ${ }^{1}$ Jumlah masalah kesehatan di Indonesia akan bertambah seiring dengan meningkatnya jumlah lansia di Indonesia jika tidak diikuti dengan pemeliharaan fungsi tubuh mereka. Penuaan menyebabkan terjadinya perubahan penurunan fungsi seperti fisik, psikologis dan sosial. Performa fisik yang mengalami penurunan pada beberapa struktur seperti struktur saraf, struktur tulang sendi, dan struktur otot yang memengaruhi efisiensi dan kesejahteraan hidup bagi lansia. ${ }^{2}$ Bertambahnya usia akan mengakibatkan penurunan fungsi koordinasi, salah satunya adalah fungsi koordinasi mata tangan. ${ }^{3}$

Koordinasi mata tangan adalah hubungan kompleks antara sistem visual dan motorik yang memiliki suatu tujuan seperti menunjuk, meraih, menggenggam, dan mencakup banyak aktivitas fungsional. ${ }^{4}$ Hampir seluruh aktivitas sehari - hari membutuhkan koordinasi mata tangan yang baik sehingga perlu dilakukan suatu pencegahan maupun peningkatan terhadap fungsi koordinasi mata tangan pada lansia. Dari hasil penelitian sebelumnya yang membandingkan koordinasi mata tangan usia dewasa dan lansia, tidak ada lansia dengan kemampuan kordinasi mata tangan yang tinggi, hanya $25 \%$ lansia dengan kemampuan koordinasi mata tangan sedang, dan $75 \%$ lansia dengan kemampuan koordinasi mata tangan rendah. ${ }^{3}$ Salah satu cara untuk mencegah maupun meningkatkan fungsi koordinasi mata tangan yaitu dengan melakukan sebuah aktivitas fisik.

Menurut WHO, aktivitas fisik merupakan seluruh gerakan dalam tubuh yang membutuhkan energi dan dihasilkan oleh otot. Tingkat aktivitas fisik masyarakat Indonesia bisa dikatakan tergolong rendah. Hal tersebut bisa dinilai dari rata-rata langkah orang Indonesia per harinya. Indonesia hanya mencatat 3.513 langkah per harinya sedangkan Jepang memiliki rata-rata mencapai 6.010 langkah per harinya. Dari hasil penelitian sebelumnya didapatkan data lansia di Kelurahan Jati Kecamatan Padang Timur yang memiliki tingkat aktivitas fisik rendah yakni 31 dari 56 orang $(70,6 \%) .{ }^{5}$ Di Bali khususnya di kabupaten Gianyar, tingkat aktivitas fisik lansia yang tergolong rendah memiliki proporsi paling tinggi yaitu sebesar $56,9 \%$, lalu lansia yang memiliki aktivitas sedang sebesar $20,8 \%$, dan lansia yang memiliki aktivitas fisik tinggi sebesar $22,2 \%{ }^{6}$ 
Salah satu aktivitas yang telah diteliti mampu meningkatkan koordinasi mata tangan adalah renang. ${ }^{7}$ Kelompok lansia yang melakukan olahraga berenang secara rutin dinyatakan mempunyai tingkat koordinasi mata tangan yang lebih baik jika dibandingkan dengan lansia yang tidak rutin melakukan olahraga renang. ${ }^{7}$ Aktivitas fisik yang dilakukan berulang kali dapat menstimulasi impuls saraf dari reseptor sensorik perifer menuju cerebellum, koneksi saraf integratif dalam cerebellum, dan sistem ekstrapiramidal menuju neuron motorik sehingga mampu meningkatkan fungsi koordinasi mata tangan pada lansia. ${ }^{7}$ Aktivitas lain yang telah diteliti mampu meningkatkan koordinasi mata tangan adalah permainan mahjong, olahraga ving tsun, olahraga tai chi, dan olahraga aerobik. ${ }^{8-10}$ Di Indonesia sendiri salah satu contoh kegiatan yang dikhususkan untuk lansia adalah senam lansia. Senam lansia biasanya rutin dilakukan satu kali setiap minggunya. Menurut hasil penelitian terdahulu, lansia yang sudah memanfaatkan fasilitas senam lansia sebesar $49,5 \%$ dan sebagian besar lansia belum mengetahui manfaat dari aktivitas fisik terhadap kesehatan tubuh mereka. ${ }^{11}$

Berdasarkan latar belakang diatas peneliti meyakini bahwa aktivitas fisik seseorang mampu untuk memengaruhi kemampuan koordinasi mata tangan pada lansia. Sejauh ini belum ada penelitian mengenai koordinasi mata tangan yang menggunakan sampel lansia di Indonesia. Peneliti pun menganggap penting untuk mencari tahu hubungan antara aktivitas fisik di Indonesia terhadap koordinasi mata tangan karena aktivitas fisik lansia suatu negara berbeda dengan negara lainnya. Penelitian ini diharapkan bisa mendorong tenaga kesehatan khususnya fisioterapi untuk meneliti lebih lanjut mengenai aktivitas fisik dan koordinasi mata tangan pada lansia di Indonesia. Maka dari itu peneliti akan mengangkat topik ini kedalam penelitian dengan judul "Hubungan Aktivitas Fisik Terhadap Koordinasi Mata Tangan pada Lansia di Desa Gerih".

\section{METODE}

Penelitian ini merupakan penelitian observasional dengan metode cross-sectional (potong lintang). Variabel independen dalam penelitian ini adalah aktivitas fisik, sedangkan variabel dependennya adalah koordinasi mata tangan. Penelitian ini dilakukan pada bulan Januari 2021 di Banjar Dirgahayu, Desa Adat Gerih, Abiansemal, Badung. Sampel dalam penelitian ini adalah 44 lansia di Desa Gerih dengan teknik pengambilan sampel total sampling karena anggota populasi relatif kecil. Kriteria inklusi adalah berjenis kelamin perempuan atau laki-laki, berusia 60 - 65 tahun, keadaan umum sehat, vital sign dalam batas normal, memiliki indeks masa tubuh yang normal (nilai IMT dalam rentang 18,5 - 24,9), memiliki penglihatan yang baik dan jika mengalami gangguan penglihatan sudah memakai alat bantu, dan bersedia secara sukarela menjadi subjek penelitian dengan menyetujui informed consent yang diberikan sebagai bukti telah bersedia menjadi sampel dalam penelitian ini. Kriteria eksklusi dalam penelitian ini adalah memiliki gangguan penglihatan berat seperti katarak dan atau kebutaan yang sudah diperiksa dokter sebelumnya, memiliki riwayat brain injury melalui wawancara serta riwayat brain injury merupakan diagnosis dokter, memiliki gangguan motorik seperti tremor menurut dokter atau fisioterapis, dan mengalami cedera muskuloskeletal pada ekstrimitas atas dan bawah menurut dokter dan fisioterapis. Kriteria drop out dalam penelitian ini adalah tidak mampu mengikuti instruksi penelitian. Penelitian ini sudah dinyatakan laik etik oleh Komisi Etik Penelitian (KEP) Fakultas Kedokteran Universitas Udayana pada surat keterangan kelaikan etik No:350/UN14.2.2.VII.14/LP/2020.

Penelitian dilaksakan dengan metode door to door atau mendatangi ke tiap rumah akibat adanya pandemi COVID - 19. Peneliti melaksanakan door to door bersama dengan tiga orang diantaranya satu orang dari puskesmas, satu orang kelian banjar, dan satu orang teman untuk melakukan dokumentasi. Hal yang dilakukan pertama kali adalah mencuci tangan dan memberikan masker kepada subjek yang didatangi. Selanjutnya dokter akan melakukan pengecekan vital sign, wawancara awal terkait umur, riwayat penyakit atau gangguan kesehatan lainya, pengukuran IMT, dan riwayat permasalahan fungsi penglihatan. Saat subjek memenuhi syarat akan diberikan informed consent dan jika bersedia akan dilanjutkan dengan pengukuran aktivitas fisik dan koordinasi mata tangan oleh peneliti. Tingkat aktivitas fisik diukur menggunakan Index Baecke. Index Baecke adalah kuesioner yang terdiri dari 15 pertanyaan. Terdapat 7 pertanyaan terkait pekerjaan, 4 pertanyaan terkait olahraga, dan 4 pertanyaan terkait kegiatan pada waktu luang. Untuk mengukur tingkat koordinasi mata tangan, tes yang digunakan adalah alternate hand wall toss test berupa lempar tangkap bola tenis ke sasaran yang tertempel di dinding digunakan dengan jarak lempar 1 meter. Sasaran pada dinding berbentuk persegi dengan ukuran $50 \times 50 \mathrm{~cm}$. Subjek melemparkan bola tenis ke arah sasaran sebanyak mungkin dalam 30 detik menggunakan satu tangan lalu ditangkap oleh tangan yang berlawanan. Jika subjek berhasil melempar dan menangkap bola, subjek akan mendapatkan nilai 1.

Semua data yang sudah terkumpul dianalisa menggunakan bantuan perangkat lunak SPSS 25.0. Karakteristik sampel dianalisis secara univariate. Shapiro Wilk Test digunakan untuk melihat apakah data berdistribusi normal atau tidak. Data dikatakan berdistribusi normal dan akan diuji menggunakan uji parametrik jika nilai $p>0,05$. Data dikatakan berdistribusi tidak normal dan akan diuji menggunakan uji non parametrik jika nilai $p<0,05$. Untuk menjelaskan hubungan antara dua variabel dan membandingkan karakteristik antara aktivitas fisik dan koordinasi mata tangan dengan menggunakan analisis parametrik pearson atau non parametrik spearman rho.

HASIL

Tabel 1. Data Karakteristik Sampel

\begin{tabular}{ccc}
\hline Variabel & Frekuensi $(\mathrm{n})$ & Persentase \\
\hline Usia & & \\
60 th & 8 & 18,2 \\
61 th & 4 & 9,1 \\
62 th & 6 & 13,6 \\
63 th & 7 & 15,9 \\
64 th & 9 & 20,5 \\
65 th & 10 & 22,7 \\
\hline
\end{tabular}


Lanjutan Tabel 1. Data Karakteristik Sampel

\begin{tabular}{lcc}
\hline \multicolumn{1}{c}{ Variabel } & Frekuensi $(\mathrm{n})$ & Persentase \\
\hline $\begin{array}{l}\text { Jenis Kelamin } \\
\text { Laki-laki }\end{array}$ & 28 & 63,6 \\
Perempuan & 16 & 36,4 \\
Pekerjaan & & \\
Petani & 14 & 31,8 \\
lbu rumah tangga & 7 & 15,9 \\
Pensiun & 7 & 15,9 \\
Pembuat banten & 6 & 13,6 \\
Penjaga toko & 5 & 11,4 \\
Pekerja pabrik & 4 & 9,1 \\
Tukang & 1 & 2,3 \\
\hline
\end{tabular}

Rentang usia sampel sesuai dengan kriteria inklusi adalah $60-65$ tahun. Jumlah sampel yang berusia 60 tahun sejumlah 8 orang $(18,2 \%)$, berusia 61 tahun sejumlah 4 orang $(9,1 \%)$, berusia 62 tahun sejumlah 6 orang $(13,6 \%)$, berusia 63 tahun sejumlah 7 orang (15,9\%), berusia 64 tahun sejumlah 9 orang (20,5\%), dan berusia 65 tahun sejumlah 10 orang $(22,7 \%)$. Jenis kelamin sampel penelitian dengan jenis kelamin perempuan sejumlah 28 orang $(63,6 \%)$ sedangkan sampel laki - laki berjumlah 16 orang $(36,4 \%)$. Mayoritas sampel lansia di Desa Gerih berprofesi sebagai seorang petani yaitu sejumlah 14 orang $(31,8 \%)$, ibu rumah tangga sejumlah 7 orang $(15,9 \%)$, pensiunan sejumlah 7 orang $(15,9 \%)$, pembuat banten sejumlah 6 orang $(13,6 \%)$, penjaga toko sejumlah 5 orang $(11,4 \%)$, pekerja pabrik sejumlah 4 orang $(9,1 \%)$, dan pertukangan sejumlah 1 orang $(2,3 \%)$.

Tabel 2. Distribusi Karakteristik Subjek berdasarkan Aktivitas Fisik

\begin{tabular}{lcccc}
\hline Aktivitas Fisik & Frekuensi & Persentase $(\%)$ & Rata-rata & Simpang Baku \\
\hline Rendah & 6 & 13,6 & & \\
Sedang & 17 & 38,6 & 7,49 & 1,17 \\
Tinggi & 21 & 47,8 & & \\
\hline Total & 44 & 100 & & \\
\hline
\end{tabular}

Pada Tabel 2. dapat dilihat bahwa dari 44 orang lansia, 6 orang (13,6\%) memiliki aktivitas fisik rendah, 17 orang $(37,6 \%)$ memiliki tingkat aktivitas fisik sedang, dan 21 orang $(47,8 \%)$ memiliki aktivitas fisik tinggi. Rata - rata tingkat aktivitas lansia di Desa Gerih adalah 7,49.

Tabel 3. Distribusi Frekuensi Karakteristik Subjek berdasarkan Koordinasi Mata Tangan

\begin{tabular}{ccccc}
\hline Koordinasi Mata Tangan & Frekuensi & Persentase (\%) & Rata-rata & Simpang Baku \\
\hline 8 & 1 & 2,3 & & \\
9 & 2 & 4,5 & & \\
10 & 5 & 11,4 & & \\
11 & 4 & 9,1 & & \\
12 & 5 & 11,4 & & \\
13 & 6 & 13,6 & 13,52 & \\
14 & 5 & 11,4 & & \\
15 & 3 & 6,8 & & \\
16 & 5 & 11,4 & & \\
17 & 4 & 9,1 & & \\
18 & 3 & 6,8 & & \\
20 & 1 & 2,3 & & \\
\hline Total & 44 & 100.0 & & \\
\hline
\end{tabular}

Pada Tabel 3. dapat dilihat bahwa nilai tes koordinasi mata tangan dari para subjek beragam. Tes koordinasi mata tangan dapat diukur menggunakan alternate hand wall toss test. Rata-rata nilai koordinasi mata tangan yang didapatkan adalah sebesar 13,52 kali lemparan sukses dengan standar deviasi 2,89.

Tabel 4. Uji Normalitas Shapiro Wilk

\begin{tabular}{lc}
\hline \multicolumn{1}{c}{ Variabel } & $p$ \\
\hline Aktivitas Fisik & 0,000 \\
Koordinasi Mata Tangan & 0,391 \\
\hline
\end{tabular}

Berdasarkan tabel 4. terdapat variabel aktivitas fisik yang memiliki $p<0,05(0,000)$ yang dapat dikatakan bahwa data variabel aktivitas fisik berdistribusi tidak normal, sedangkan variabel koordinasi mata tangan dengan $p>0,05$ $(0,391)$ dapat diartikan bahwa distribusi variabel tersebut adalah normal.

Tabel 5. Hubungan antara Aktivitas Fisik terhadap Koordinasi Mata Tangan

\begin{tabular}{ccc}
\hline Korelasi Variabel & Korelasi & $p$ \\
\hline Aktivitas Fisik terhadap Koordinasi Mata Tangan & 0,359 & 0.017 \\
\hline
\end{tabular}

Pada Tabel 5. dapat dilihat bahwa aktivitas fisik memiliki hubungan yang signifikan dengan koordinasi mata tangan, di mana nilai $p=0,017(p<0,05)$ dengan nilai koefisien korelasi sebesar 0,359 dan bernilai positif. Ini 
menunjukkan adanya hubungan lemah, signifikan, dan berbanding lurus antara aktivitas fisik terhadap koordinasi mata tangan pada lansia di Desa Gerih. Berdasarkan hasil tersebut, dapat dikatakan bahwa semakin tinggi nilai aktivitas fisik maka semakin tinggi tingkat koordinasi mata tangannya.

\section{DISKUSI}

Berdasarkan hasil pengujian data dengan menggunakan analisis non parametrik spearman rho (tabel 5) dapat dilihat bahwa aktivitas fisik memiliki hubungan yang signifikan dengan koordinasi mata tangan, di mana nilai $p=0,017$ $(p<0,05)$ dengan nilai koefisien korelasi sebesar 0,359 dan bernilai positif. Ini menunjukkan adanya hubungan lemah, signifikan, dan berbanding lurus antara aktivitas fisik terhadap koordinasi mata tangan pada lansia di Desa Gerih. Berdasarkan hasil tersebut, dapat dikatakan bahwa semakin tinggi nilai aktivitas fisik maka semakin tinggi tingkat koordinasi mata tangannya.

Aktivitas fisik merupakan seluruh gerakan dalam tubuh yang membutuhkan energi dan dihasilkan oleh otot. Kegiatan yang termasuk dalam aktivitas fisik adalah olahraga atau kegiatan lain yang melibatkan gerakan tubuh serta dilakukan sebagai bagian dari bekerja, bermain, pekerjaan rumah, kegiatan rekreasi, dan transportasi aktif. Terdapat beberapa penelitian pendukung yang menyatakan aktivitas fisik yang berpengaruh terhadap koordinasi mata tangan.

Salah satu penelitian dengan hasil yang sesuai dengan penelitian ini adalah penelitian yang membahas mengenai pengaruh usia dan tingkat aktivitas fisik terhadap koordinasi mata tangan. Koordinasi mata tangan dalam penelitian tersebut diukur menggunakan Visual Display Unit (VDU). Dengan menggunakan teknik analisis post-hoc test dinyatakan ada hubungan yang signifikan antara aktvitas fisik terhadap koordinasi mata tangan $(p<0,05){ }^{3}$

Penelitian lain yang mendukung hasil penelitian ini adalah penelitian yang membandingkan koordinasi mata tangan pada pemain mahjong dengan bukan pemain mahjong. ${ }^{12}$ Mahjong merupakan sebuah permainan dari China yang dimainkan oleh empat orang. Permainan ini menuntut strategi, kecakapan, peruntungan, kalkulasi, dan kecerdasan dari pemainnya. Lansia yang bermain mahjong memiliki koordinasi yang lebih baik dibandingkan dengan lansia yang bukan pemain mahjong $(p<0,05) .{ }^{12}$ Selain permainan mahjong aktivitas fisik yang diketahui memiliki pengaruh terhadap koordinasi mata tangan adalah olahraga ving tsun. ${ }^{8}$

Olahraga ving tsun yang dilakukan secara rutin mampu meningkatkan koordinasi mata tangan. Kelompok yang rutin melakukan olahraga ving-tsun selama 4 minggu mengalami peningkatan koordinasi mata tangan yang signifikan $(p<0,05)$ jika dibandingkan kelompok kontrol yang tidak melakukan olahraga ving tsun. Olahraga lain yang mampu memengaruhi kemampuan koordinasi mata tangan adalah olahraga renang. ${ }^{8}$

Terdapat juga penelitian yang tidak mendukung hasil penelitian ini yang tidak menemukan perbedaan yang signifikan antara kelompok eksperimen dan kelompok kontrolnya. ${ }^{13}$ Kelompok eksperimen diberikan latihan interactive cognitive-motor training sebanyak 3 kali dalam seminggu dan rutin dilakukan selama 8 minggu dan kelompok kontrol hanya melakukan aktivitas seperti membaca koran dan permainan kata. Setelah diuji menggunakan independent $t$ test ditemukan tidak terdapat perbedaan yang signifikan antara kelompok kontrol dan kelompok eksperimen $(p>0,05) .{ }^{13}$

Koordinasi mata tangan adalah hubungan kompleks antara sistem visual dan motorik yang bergantung pada penglihatan untuk membantu mengarahkan gerakan yang mencakup banyak aktivitas fungsional. ${ }^{4}$ Bertambahnya usia akan mengakibatkan penurunan fungsi sistem saraf dan akan memengaruhi fungsi koordinasi mata tangan. ${ }^{3}$ Secara fisiologis, pertumbuhan saraf yang dapat menghambat penurunan fungsi saraf pada lansia dapay distimulasi dengan aktivitas fisik. Aktivitas fisik juga mampu meningkatkan aliran darah pada otak. Seiring bertambahnya aliran darah, otak akan mendapat lebih banyak oksigen dan nutrisi. Oksigen dan nutrisi akan menjaga sel saraf sehingga lebih lambat mengalami kerusakan. ${ }^{14}$

Pada penelitian ini aktivitas fisik diukur menggunakan kuisioner baecke dan koordinasi mata tangan diukur menggunakan alternate hand wall toss test. Kuisioner baecke menilai aktivitas fisik seseorang secara menyuluruh mulai dari pekerjaan, olahraga, dan kegiatan di waktu luang. Mayoritas penelitian sebelumnya mengukur pengaruh satu jenis aktivitas fisik yang banyak menggunakan tangan terhadap kemampuan koordinasi mata tangan seperti permainan mahjong, olahraga ving tsun, dan renang. Berbeda dengan penelitian ini yang mengukur aktivitas fisik seseorang secara umum dan menyeluruh. Peneliti beranggapan hal inilah yang membuat hubungan antar kedua variabel ini memiliki hubungan yang rendah.

Terdapat beberapa batasan dan kelemahan dari penelitian ini. Alat ukur Alternate Hand Wall Toss Test yang digunakan sebagai alat ukur kemampuan koordinasi mata tangan merupakan alat ukur yang masih sedikit digunakan pada lansia, meski memiliki validitas dan reliabilitas yang tinggi. Kelemahan lainnya adalah variabel yang dikontrol masih bisa ditambahkan. Fungsi kognitif adalah salah satu variabel kontrol yang dapat ditambahkan. Fungsi kognitif tidak dikontrol dalam penelitian ini dikarenakan keterbatasan waktu saat penelitian dilapangan akibat situasi pandemi COVID-19.

\section{KESIMPULAN}

Dalam uji analisis statistik spearman rho yang dilakukan, ditemukan nilai $p=0,017$, apabila $(p<0,05)$ dapat dikatakan bahwa terdapat hubungan yang signifikan antara aktivitas fisik terhadap koordinasi mata tangan pada lansia di Desa Gerih. Didapatkan nilai koefisien korelasi sebesar 0,359 dan bernilai positif.

\section{DAFTAR PUSTAKA}

1. Badan Pusat Statistik. Provinsi Bali Dalam Angka 2016. Denpasar: BPS Provinsi Bali; 2016.

2. Jamrern R, Singnoy C, Suwanna P, Somsongkul V. The Effect of a PARA Rubber Ball Training Program on the Hand and Arm Strength and the Hand-Eye Coordination of Older Adults. J Heal Sci. 2019;9(1):12-8.

3. Halewyck F Van, Lavrysen A, Levin O, Boisgontier MP, Elliott D, Helsen WF. Both age and physical activity level impact on eye-hand coordination. Hum Mov Sci. 2014 Aug;36:80-96. 
4. Rizzo JR, Hosseini M, Wong EA, Mackey WE, Fung JK, Ahdoot E, et al. The intersection between ocular and manual motor control: Eye-hand coordination in acquired brain injury. Front Neurol. 2017;8:227.

5. Muzamil MS, Afriwardi A, Martini RD. Hubungan Antara Tingkat Aktivitas Fisik dengan Fungsi Kognitif pada Usila di Kelurahan Jati Kecamatan Padang Timur. J Kesehat Andalas. 2014 May;3(2).

6. Lestari MW, Weta IW. Status Gizi Lansia Berdasarkan Pengetahuan dan Aktivitas Fisik, di Wilayah Kerja Puskesmas Sukawati 1, Gianyar, Bali. Jkk. 2017;4(2):56-63.

7. Hübner L, Voelcker-Rehage C. Does physical activity benefit motor performance and learning of upper extremity tasks in older adults? - A systematic review. Eur Rev Aging Phys Act. 2017;14(1):1-19.

8. Fong SSM, Ng SSM, Cheng YTY, Wong JYH, Yu EYT, Chow GCC, et al. Effects of Ving Tsun Chinese Martial Art Training on Upper Extremity Muscle Strength and Eye-Hand Coordination in Community-Dwelling MiddleAged and Older Adults: A Pilot Study. Evidence-based Complement Altern Med. 2016;1-7.

9. Lee KYT, Hui-chan CWY, Tsang WWN. The effects of practicing sitting Tai Chi on balance control and eye-hand coordination in the older adults : a randomized controlled trial. 2015;37(9):790-4.

10. Stern M, College A, Valley J. Does combined cognitive training and physical activity training enhance cognitive abilities more than either alone? A four-condition randomized controlled trial among healthy older adults. 2013;5:1-12.

11. Novitasari SD. Bentuk Bentuk Partisipasi Lansia dalam Pelayanan Kesehatan POSYANDU Lansia. Universitas Negeri Semarang; 2017.

12. Tsang WWN, Wong GCK, Gao KL. Mahjong playing and eye-hand coordination in older adults-a cross-sectional study. J Phys Ther Sci. 2016;28(10):2955-60.

13. Chan PT, Chang WC, Chiu HL, Kao CC, Liu D, Chu H, et al. Effect of interactive cognitive-motor training on eyehand coordination and cognitive function in older adults. BMC Geriatr. 2019;19(1):1-10.

14. Sauliyusta M, Rekawati E. Aktivitas Fisik Memengaruhi Fungsi Kognitif Lansia. J Keperawatan Indones. 2016;19(2):71-7. 